\title{
Time of Nitrogen Supply in Yield and Industrial Quality of Oat Grains by Agricultural Condition
}

\author{
Adriana Roselia Kraisig (Corresponding author)
}

Exact Sciences and Engineering Department, Regional University of the Northwest of Rio Grande do Sul, Street of Comércio 3000, Universitário, Ijuí/RS - Brazil

$$
\text { Tel: +55 (55) 99213-1430Ｅ-mail: maryshelei@yahoo.com.br }
$$

José Antonio Gonzalez da Silva

Agrarian Studies Department, Regional University of the Northwest of Rio Grande do Sul, Street of Comércio 3000, Universitário, Ijuí/RS - Brazil

E-mail: jagsfaem@yahoo.com.br

\section{Ivan Ricardo Carvalho}

Agrarian Studies Department, Regional University of the Northwest of Rio Grande do Sul, Street of Comércio 3000, Universitário, Ijuí/RS - Brazil

E-mail: carvalho.irc@gmail.com

Francine Lautenchleger

Midwestern Parana State University, Street Presidente Zacarias, 875, Guarapuava/PR Brazil

E-mail: francinelautenchleger@hotmail.com

Ângela Teresinha Woschinski De Mamann

Federal Institute of Education, Science and Technology of Rio Grande do Sul, Street Nelsi Ribas Fritsch, 1111, Neighborhood Esperança, Ibirubá/RS - Brazil

E-mail: angela.mamann@ibiruba.ifrs.edu.br

\section{Juliana Maria Fachinetto}

Agrarian Studies Department, Regional University of the Northwest of Rio Grande do Sul, 
Street of Comércio 3000, Universitário, Ijuí/RS - Brazil

E-mail: juliana.fachinetto@unijui.edu.br

\section{Laura Mensch Pereira}

Agrarian Studies Department, Regional University of the Northwest of Rio Grande do Sul, Street of Comércio 3000, Universitário, Ijuí/RS - Brazil

E-mail: lauramensch@gmail.com

\section{Natiane Carolina Ferrari Basso}

Agrarian Studies Department, Regional University of the Northwest of Rio Grande do Sul, Street of Comércio 3000, Universitário, Ijuí/RS - Brazil

E-mail: natiane.ferrari@gmail.com

\section{Claudia Vanessa Argenta}

Agrarian Studies Department, Regional University of the Northwest of Rio Grande do Sul, Street of Comércio 3000, Universitário, Ijuí/RS - Brazil

E-mail: claudia_argenta@yahoo.com

\section{Leonardo Norbert}

Agrarian Studies Department, Regional University of the Northwest of Rio Grande do Sul, Street of Comércio 3000, Universitário, Ijuí/RS - Brazil

E-mail: norbert.leonardo6@gmail.com

\section{Julio Daronco Berlezi}

Agrarian Studies Department, Regional University of the Northwest of Rio Grande do Sul, Street of Comércio 3000, Universitário, Ijuí/RS - Brazil

E-mail: julio.berlezi28@ hotmail.com

Received: June 8, 2020

doi:10.5296/jas.v8i4.17249
Accepted: July 27, $2020 \quad$ Published: August 4, 2020

URL: https://doi.org/10.5296/jas.v8i4.17249 


\section{Abstract}

The timing of nitrogen application in oats improves the efficiency of use of the nutrient, expressing the yield and industrial quality of grains. The objective of the study is to indicate the appropriate timing of nitrogen supply on the yield and industrial quality of oat grains, considering the use of low and high dose of nitrogen at sowing and favorable and unfavorable years for cereal growing in soybean/oat system. The experiment was conducted in the years 2016, 2017 and 2018, in Augusto Pestana, RS, Brazil. The experimental design was a randomized block with four replications in a $2 \times 4$ factorial, for two doses of nitrogen at sowing ( 5 and $25 \mathrm{~kg} \mathrm{ha}^{-1}$ ), changing the top dressing dose by the total supplied of $70 \mathrm{~kg} \mathrm{ha}^{-1}$, in the expectation grain yield of $4000 \mathrm{~kg} \mathrm{ha}^{-1}$, with time of supply at $0,10,30$ and 60 days after emergence. In an unfavorable and intermediate year for the growing of oats, it is necessary to increase the dose of the nutrient at sowing in order to favor greater amplitude of the time of application in top dressing. In a favorable year, whether low or high, this range of application is guaranteed. Regardless of the reduced and high dose of nitrogen at sowing, the greatest expression of grain and industry yield occurs with the nutrient applied at 30 and 35 days after emergence in an unfavorable year, 35 days in an intermediate year and 40 to 45 days in a favorable year, respectively.

Keywords: Avena sativa, rainfall, regression, sustainability, temperature

\section{Introduction}

In the globalized market, the use of strategies aimed at increasing the yield and quality of oat grains is decisive. Therefore, the potential of oat yield is associated with the genetic characteristics of the cultivars and their interaction with meteorological conditions and management technologies. Among the management technologies, the dose and timing of nitrogen application are fundamental to increase grain yield and quality (Ma et al., 2017; Marolli et al., 2018).

The definition of the nitrogen dose in oats depends on the organic matter content of the soil, the previous crop and the grain yield expectations (Mantai et al., 2016; Silva et al., 2016). On the other hand, the most propitious moment for top dressing fertilization falls only on the phenology of the plant linked to the period of greatest nutrient deficiency in the formation of production components (Bredemeier et al., 2013; Mantai et al., 2015). The technical indications of oats in Brazil recommend as the fertilization time between the beginning of the tillering (stage V3) and the beginning of the elongation (stage V6), interval around 30 to 60 days after emergence, characterizing the period of greatest demand (Arenhardt et al., 2015; Marolli et al., 2017).

The period between the beginning of the tillering and the elongation shows a great gap in the decision of the appropriate moment of nitrogen application. In this way, the greater efficiency of nitrogen use by the time of supply in top dressing can be better defined in the interval of greatest demand, considering conditions of low and high dose of nitrogen at sowing and different meteorological conditions for agricultural years favorable and unfavorable to oat growing.

The objective of the study is to indicate the appropriate timing of nitrogen supply on the yield and industrial quality of oat grains, considering the use of low and high dose of nitrogen at sowing and favorable and unfavorable years for cereal growing in soybean/oat system. 


\section{Materials and Methods}

\subsection{Crop Area Description}

The experiment was conducted in the field, in the agricultural years of 2016, 2017 and 2018, in Augusto Pestana, RS, Brazil (28 $26^{\circ}$ ' $30^{\prime}$ ' 'S and $54^{\circ} 0^{\prime}$ ' 58' $\mathrm{W}$ and $400 \mathrm{~m}$ altitude). The soil in the experimental area is classified as an Oxisol and the region's climate, according to the Köppen classification, is of the Cfa type, with hot summer without a dry season. The air temperature $\left({ }^{\circ} \mathrm{C}\right)$ and rainfall $(\mathrm{mm})$ information for the analysis of the meteorological conditions of the agricultural year were obtained by the Total Automatic Station installed 500 $\mathrm{m}$ from the experiment.

Twenty days before sowing, soil analysis was carried out, determining the following chemical characteristics of the soybean/oat system: $\left(\mathrm{pH}=6.2 ; \mathrm{P}=33.9 \mathrm{mg} \mathrm{dm}^{-3} ; \mathrm{K}=200 \mathrm{mg}\right.$ $\mathrm{dm}^{-3} ; \mathrm{OM}=3.0 \% ; \mathrm{Al}=0 \mathrm{cmolc} \mathrm{dm}^{-3} ; \mathrm{Ca}=6.5 \mathrm{cmolc} \mathrm{dm}^{-3}$ and $\mathrm{Mg}=2.5 \mathrm{cmolc} \mathrm{dm}^{-3}$. Sowing was carried out in the third week of June with a seeder-fertilizer in the composition of the plot with 5 lines of $5 \mathrm{~m}$ in length and spacing between lines of $0.20 \mathrm{~m}$, forming the experimental unit of $5 \mathrm{~m}^{2}$. The population density used was 400 viable seeds $\mathrm{m}^{-2}$. During the execution of the study, applications of tebuconazole fungicide at a dosage of $0.75 \mathrm{~L} \mathrm{ha}^{-1}$ were performed. Weed control was performed with metsulfuron-methyl herbicide at a dose of $4 \mathrm{~g}$ $\mathrm{ha}^{-1}$. At sowing, 45 and $30 \mathrm{~kg} \mathrm{ha}^{-1}$ of $\mathrm{P}_{2} \mathrm{O}_{5}$ and $\mathrm{K}_{2} \mathrm{O}$ were applied, respectively, based on the levels of $\mathrm{P}$ and $\mathrm{K}$ in the soil with the expectation of grain yield of $4 \mathrm{tha}^{-1}$.

\subsection{Experimental Design}

The experiment was conducted in a randomized block design with four replications in a $2 \times 4$ factorial scheme, for two doses of nitrogen at sowing ( 5 and $25 \mathrm{~kg} \mathrm{ha}^{-1}$ ), changing the top dressing dose by the total supplied of $70 \mathrm{~kg} \mathrm{ha}^{-1}$, in the expectation of grain yield of $4000 \mathrm{~kg}$ $\mathrm{ha}^{-1}$, with the provision of top dressing in four application times $(0,10,30$ and 60 days after emergence), totaling 32 experimental units in the soybean/oat succession system.

In the study, variables related to yield and industrial quality of oat grains were evaluated. Grain yield $\left(\mathrm{GY}, \mathrm{kg} \mathrm{ha}^{-1}\right)$ was obtained by cutting three central lines of each plot during the harvest maturity period, grain moisture close to $22 \%$. They were tracked with a stationary harvester and directed to the laboratory to correct grain moisture to $13 \%$. The hectoliter mass (HM, $\mathrm{kg}$ $\mathrm{hl}^{-1}$ ) was obtained from the grain sample from each plot, directed to the equipment with a known volume of $250 \mathrm{~cm}^{3}$, the mass obtained in this volume was converted to $\mathrm{kg} \mathrm{hl}^{-1}$. Industrial yield (IY, $\mathrm{kg} \mathrm{ha}^{-1}$ ) was obtained by the product of grain yield with the number of grains greater than $2 \mathrm{~mm}$ and the husking index (IY $=\mathrm{GY} \times \mathrm{NG}>2 \mathrm{~mm} \times \mathrm{HI}$ ). The number of grains larger than two millimeters $(\mathrm{NG}>2 \mathrm{~mm}, \mathrm{n})$ was obtained by randomly counting one hundred grains, which are placed in a $2 \mathrm{~mm}$ mesh sieve and those above this dimension are counted. From the grains larger than $2 \mathrm{~mm}$, a sample of 50 grains is taken, which are weighed on a precision scale to obtain the grain mass from grains larger than $2 \mathrm{~mm}$. Then, these grains are dehusked for weighing the caryopsis mass. In this way, the husking index (HI, $\mathrm{g} \mathrm{g}^{-1}$ ) was obtained by the ratio between the mass of the caryopsis and the mass of grains.

\subsection{Statistical Model}

When meeting the assumptions of homogeneity and normality via the Bartlett test, analysis of variance was performed to detect the significance of the main and interaction effects. Based on this information, the test of comparison of means by Scott and Knott was carried out at the level 
of 0.05 probability of error. Afterwards, the quadratic equation (Equation 1) was adjusted to the estimate of the ideal time of supply of the nutrient in top dressing (Equation 2) in the different fertilization doses at sowing and top dressing to the expectation of $4000 \mathrm{~kg} \mathrm{ha}^{-1}$ of grains.

$$
\begin{gathered}
Y=b_{0} \pm b_{1} x \pm b_{2} x^{2} \\
\text { Time }=-\frac{b_{1}}{2 b_{2}}
\end{gathered}
$$

\section{Results and Discussion}

In 2018 (Figure 1A), the average maximum temperature close to the application of nitrogen was the lowest of approximately $15^{\circ} \mathrm{C}$ in relation to the other years. At the time of nitrogen application, the soil presented adequate humidity conditions due to the accumulation of rain from the previous days. The high volume of rainfall during the cycle provided periods of less sunshine, which reduces the efficiency of photosynthesis by the plant. The average grain yield presented in Table 1, justifies a reasonable yield, characterizing as an intermediate year (IY) for the growing of oats. In 2017 (Figure 1B), when nitrogen was applied, the maximum temperature averages were higher around $24{ }^{\circ} \mathrm{C}$ compared to 2016 and 2018. The nitrogen applied in top dressing at 30 days after emergence, was followed by a rainfall volume greater than $50 \mathrm{~mm}$, a volume also observed close to the grain harvest, a condition that favors greater nitrogen losses through leaching and losses due to excess rain in the maturation, characterizing the year 2017 as unfavorable (UY) to growing. In the 2016 agricultural year (Figure 1C), the average maximum temperature obtained at the time of nitrogen application was around $20{ }^{\circ} \mathrm{C}$. The application of nitrogen occurred in favorable conditions of soil moisture due to rains that occurred in days prior to fertilization. In this condition, according to Table 1, although the total rainfall volume was the lowest, the adequate distribution of rainfall throughout the cycle was decisive in the higher grain yield, with an average yield of around $4000 \mathrm{~kg} \mathrm{ha}^{-1}$, characterizing a favorable year (FY) for growing.

Rainfall stands out as one of the main factors responsible for variations in agricultural yield. Prior knowledge of rainfall conditions can indicate ways of management that ensure the success of the activity (Arenhardt et al., 2015; Scremin et al., 2017).

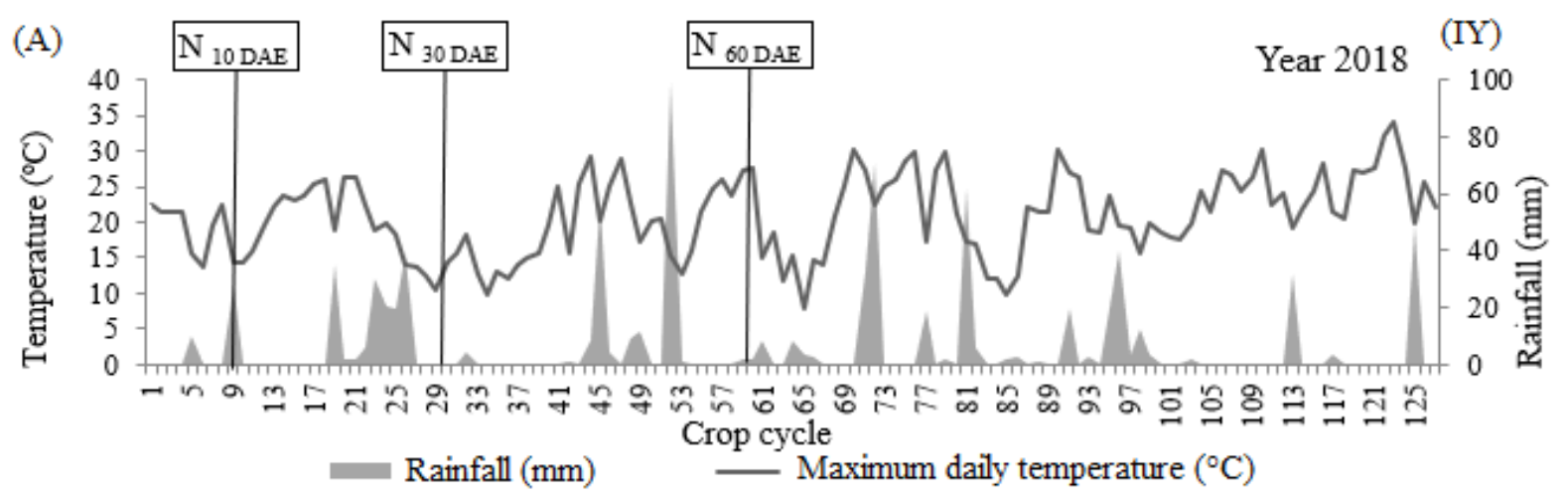



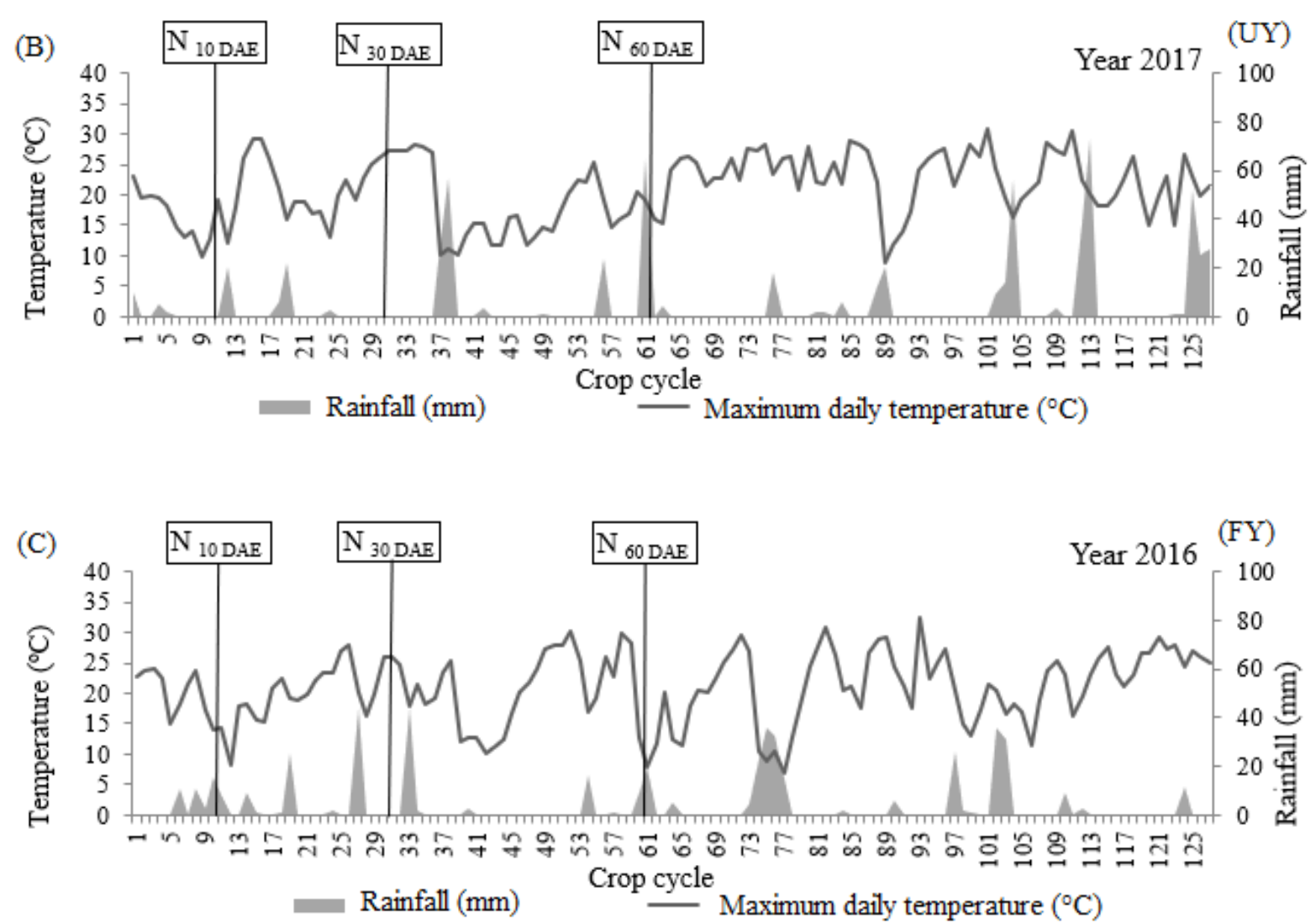

Figure 1. Data of rainfall and maximum daily temperature in the oat crop and the positioning of nitrogen supply times throughout the cycle

$\mathrm{N}_{10}$ - Application of nitrogen 10 days after emergence; $\mathrm{N}_{30}$ - Application of nitrogen 30 days after emergence; $\mathrm{N}_{60}$ - Application of nitrogen 60 days after emergence; DAE - Days after the emergency; IY - Intermediate year; UY - Unfavorable year; FY - Favorable year. Data obtained from the weather station located at the Regional Institute for Rural Development/IRDeR/UNIJUÍ, 2016, 2017 and 2018

In winter cereals, rainfall without large volumes favors adequate soil moisture and is well distributed throughout the growing cycle, characterizes meteorological conditions favorable to the management of nitrogen to the greatest expression of yield (Marolli et al., 2018; Silva et al., 2020). In addition to rainfall, the air temperature also acts with a strong effect on the dynamics of nitrogen utilization and expression of yield. Temperature acts as a catalyst for biological processes, which is why plants require a minimum and maximum temperature for normal physiological activities (Tonin et al., 2014; Marolli et al., 2017). In cereals such as oats and wheat, the milder temperatures and radiation quality favor tillering and filling of grains, with direct effects on productivity (Arenhardt et al., 2015; Trautmann et al., 2020). In nitrogen management, the occurrence of high volume and/or intensity of rainfall, right after fertilization, reduces the plant's efficiency due to the lack of oxygenation and generates the loss of the nutrient by leaching (Ercoli et al., 2013; Scremin et al., 2017). The same authors also report that high temperatures reduce the efficiency of fertilization due to losses by volatilization. 


\section{$\triangle$ Macrothink}

The results obtained by the analysis of variance show significant differences between the nitrogen doses in the sowing with the time of supply in top dressing, as well as the presence of interaction, in each year of growing (not shown). Therefore, the averages and regression analyzes are presented unfolding the effects of this interaction. In Table 1, of averages, in the intermediate year of growing (2018), the lowest dose of nitrogen at sowing indicates the need for anticipation of supply, however, the highest dose allows to extend the moment of application, not differentiating the points of 10 and 30 days after the emergence. In the unfavorable year for growing (2017), the need to increase the nitrogen dose at sowing with an appropriate time at the points of 10 and 30 days after emergence is highlighted. In the favorable year (2016), the low and high doses of nitrogen at sowing show points of maximum expression of grain yield at 10 and 30 days after emergence. In addition, with the possibility of extending the moment of application to the point of 60 days after emergence at the highest dose of nitrogen at sowing. In general, regardless of the condition of the agricultural year, the time of application of nitrogen at points 10 and 30 days show the most expressive results of grain yield, in a low and high dose of the nutrient at sowing.

Table 1. Averages of grain and industry yield and hectoliter mass of oats by the time of nitrogen supply at sowing/top dressing in the soybean/oat system

\begin{tabular}{|c|c|c|c|c|c|c|}
\hline \multirow{2}{*}{ Year } & \multirow{2}{*}{$\begin{array}{c}\text { N Dose Sowing } \\
\left(\mathrm{kg} \mathrm{ha}^{-1}\right)\end{array}$} & \multirow{2}{*}{$\begin{array}{l}\text { N Dose Top } \\
\text { Dressing } \\
\left(\mathrm{kg} \mathrm{ha}^{-1}\right)\end{array}$} & \multicolumn{4}{|c|}{ N Time Top Dressing (days) } \\
\hline & & & 0 & 10 & 30 & 60 \\
\hline & & & \multicolumn{4}{|c|}{ Grain yield $\left(\mathrm{kg} \mathrm{ha}^{-1}\right)$} \\
\hline 2018 & 5 & 65 & $2916 \mathrm{Ba}$ & $3900 \mathrm{Aa}$ & $3822 \mathrm{Ab}$ & $3658 \mathrm{Bb}$ \\
\hline (IY) & 25 & 45 & $3063 \mathrm{Ba}$ & $4085 \mathrm{Aa}$ & $4090 \mathrm{Aa}$ & $3851 \mathrm{Ba}$ \\
\hline 2017 & 5 & 65 & $2249 \mathrm{Bb}$ & $2664 \mathrm{Ab}$ & $2702 \mathrm{Ab}$ & $2331 \mathrm{Bb}$ \\
\hline (UY) & 25 & 45 & $2451 \mathrm{Ba}$ & $3001 \mathrm{Aa}$ & $2900 \mathrm{Aa}$ & $2798 \mathrm{Ba}$ \\
\hline 2016 & 5 & 65 & $3562 \mathrm{Cb}$ & $4190 \mathrm{Aa}$ & $4096 \mathrm{Aa}$ & $3830 \mathrm{Ba}$ \\
\hline$(\mathrm{FY})$ & 25 & 45 & $3892 \mathrm{Ba}$ & $4131 \mathrm{Aa}$ & 4179 Аa & $4098 \mathrm{Aa}$ \\
\hline \multirow{2}{*}{ Average } & 5 & 65 & $2909 \mathrm{Ba}$ & $3585 \mathrm{Aa}$ & $3540 \mathrm{Aa}$ & $3273 \mathrm{Bb}$ \\
\hline & 25 & 45 & $3135 \mathrm{Ca}$ & $3739 \mathrm{Aa}$ & $3723 \mathrm{Aa}$ & $3582 \mathrm{Ba}$ \\
\hline & & & \multicolumn{4}{|c|}{ Hectoliter mass $\left(\mathrm{kg} \mathrm{ha}^{-1}\right)$} \\
\hline 2018 & 5 & 65 & $47 \mathrm{Bb}$ & $54 \mathrm{Aa}$ & 53 Aa & $51 \mathrm{Ba}$ \\
\hline$(\mathrm{IY})$ & 25 & 45 & $51 \mathrm{Ba}$ & $55 \mathrm{Aa}$ & $55 \mathrm{Aa}$ & $51 \mathrm{Ba}$ \\
\hline 2017 & 5 & 65 & $46 \mathrm{Ba}$ & $50 \mathrm{Aa}$ & $51 \mathrm{Aa}$ & $46 \mathrm{Ba}$ \\
\hline (UY) & 25 & 45 & $45 \mathrm{Ba}$ & $50 \mathrm{Aa}$ & $51 \mathrm{Aa}$ & $45 \mathrm{Ba}$ \\
\hline 2016 & 5 & 65 & $52 \mathrm{Bb}$ & $55 \mathrm{Aa}$ & $55 \mathrm{Aa}$ & $51 \mathrm{Bb}$ \\
\hline$(\mathrm{FY})$ & 25 & 45 & $56 \mathrm{Aa}$ & $56 \mathrm{Aa}$ & $56 \mathrm{Aa}$ & $55 \mathrm{Aa}$ \\
\hline \multirow{2}{*}{ Average } & 5 & 65 & $48 \mathrm{Ba}$ & $53 \mathrm{Aa}$ & $53 \mathrm{Aa}$ & $49 \mathrm{Ba}$ \\
\hline & 25 & 45 & $51 \mathrm{Ba}$ & $54 \mathrm{Aa}$ & $54 \mathrm{Aa}$ & $50 \mathrm{Ba}$ \\
\hline & & & \multicolumn{4}{|c|}{ Industrial yield $\left(\mathrm{kg} \mathrm{ha}^{-1}\right)$} \\
\hline 2018 & 5 & 65 & $965 \mathrm{Cb}$ & $1549 \mathrm{Aa}$ & $1510 \mathrm{Ab}$ & $1252 \mathrm{Bb}$ \\
\hline$(\mathrm{IY})$ & 25 & 45 & $1237 \mathrm{Ca}$ & $1651 \mathrm{Ba}$ & $1835 \mathrm{Aa}$ & $1471 \mathrm{Ba}$ \\
\hline 2017 & 5 & 65 & $710 \mathrm{Cb}$ & $1265 \mathrm{Ab}$ & $1363 \mathrm{Ab}$ & $1080 \mathrm{Ba}$ \\
\hline (UY) & 25 & 45 & $1031 \mathrm{Ba}$ & $1407 \mathrm{Aa}$ & $1554 \mathrm{Aa}$ & $1193 \mathrm{Ba}$ \\
\hline 2016 & 5 & 65 & $1710 \mathrm{Bb}$ & $2081 \mathrm{Ab}$ & $2002 \mathrm{Ab}$ & $1920 \mathrm{Ab}$ \\
\hline$(\mathrm{FY})$ & 25 & 45 & $2011 \mathrm{Ba}$ & $2348 \mathrm{Aa}$ & $2290 \mathrm{Aa}$ & $2242 \mathrm{Aa}$ \\
\hline \multirow{2}{*}{ Average } & 5 & 65 & $1632 \mathrm{Cb}$ & $1632 \mathrm{Aa}$ & $1625 \mathrm{Ab}$ & $1417 \mathrm{Bb}$ \\
\hline & 25 & 45 & $1426 \mathrm{Ca}$ & $1802 \mathrm{Aa}$ & $1893 \mathrm{Aa}$ & $1635 \mathrm{Ba}$ \\
\hline
\end{tabular}

The total dose of $70 \mathrm{~kg} \mathrm{ha}^{-1}$ is considered for the expectation of $4000 \mathrm{~kg} \mathrm{ha}^{-1}$ of grains. Means followed by the same lowercase letters in the column and uppercase letters in the horizontal do not differ statistically from each other at $\mathrm{p} \leq 0.05$ by the Tuckey test. IY - Intermediate year; UY - Unfavorable year; FY - Favorable year

In Table 1, in the analysis of the hectoliter mass, in an unfavorable (2017) and intermediate 
year (2018) to the growing, the best time of nitrogen application is at the points of 10 and 30 days after emergence, either in low and high dose of the nutrient at sowing. In a favorable year (2016), the reduced dose of nitrogen at sowing shows greater expression of the variable also at the points of 10 and 30 days after emergence. It is noteworthy that the increase in nutrient at sowing provides a range of application in top dressing that goes from the absence to the point of 60 days after emergence in the greatest expression of the hectoliter mass. Regardless of the condition of the agricultural year, the nitrogen supply period at 10 and 30 days after emergence promotes maximum expression of the hectolitric mass in a low and high dose of nitrogen at sowing. In Table 1, from the analysis of averages of the industrial yield of oat grains (cariopse yield), the intermediate year (2018) shows the point of 10 and 30 days after emergence as the most expressive in reduced dose of nitrogen at sowing, however, the increase in the nutrient dose shows the need for more punctual supply at 30 days after the emergence. In the unfavorable year of growing (2017) the high nitrogen condition at sowing shows the most expressive results when provided at 10 and 30 days after emergence. In the favorable year (2016), the highest dose of nitrogen at sowing also shows promising results of industrial yield with the time of supply at 10,30 and 60 days after emergence. In this variable, the favorable and unfavorable year of growing qualify the highest dose of the nutrient with the greatest range of application, unlike the intermediate year. In general, the reduced dose of nitrogen at sowing requires an advance of supply at 10 days after emergence, however, the elevation of the nutrient promotes amplitude of application at 10 and 30 days after emergence. These results indicate that the use of the highest dose of nitrogen at sowing extends the supply period, making it possible to combine the management of fertilization with the most suitable conditions of climate and soil with the expression of grain and industry yield.

In Table 2, of the regression equation in the soybean/oat system, the variables grain yield, hectoliter mass and industrial yield show significant quadratic behavior, regardless of the condition of the agricultural year and nitrogen dose at sowing. From these equations, the optimum point for the timing of nitrogen in top dressing was defined under the different growing conditions. In the intermediate year (2018), the maximum expression of grain yield was obtained at 35 days after emergence, regardless of the nutrient dose at sowing. The equations established in the doses of 5 and $25 \mathrm{~kg} \mathrm{ha}^{-1}$ at sowing show expected yield at the ideal time with 4041 and $4296 \mathrm{~kg} \mathrm{ha}^{-1}$, respectively. Still in 2018 for the hectoliter mass, regardless of the dose provided at sowing, the ideal application time for top dressing was around 45 days after emergence of oat seedlings, with the optimum dose providing an opportunity to reach $55 \mathrm{~kg} \mathrm{hl}^{-1}$ in both conditions. The ideal time for nitrogen fertilization in top dressing showed an optimum point equal to that indicated for grain yield, with 35 days after emergence, regardless of the dose provided at sowing, allowing for a low and high dose of nutrient at sowing to obtain 1614 and $1872 \mathrm{~kg} \mathrm{ha}^{-1}$ of industrial yield, respectively. 
Table 2. Regression and estimation of the ideal nitrogen supply time for grain, industry and hectoliter mass of oats in the soybean/oat system

\begin{tabular}{|c|c|c|c|c|}
\hline$Y=b_{0} \pm b_{1} x \pm b_{2} x^{2}$ & $\begin{array}{c}\mathrm{P} \\
\left(\mathrm{b}_{\mathrm{i}} \mathrm{x}^{\mathrm{n}}\right)\end{array}$ & $\mathrm{R}^{2}$ & $\begin{array}{l}\text { Ideal Times N Top Dressing } \\
\text { (days) }\end{array}$ & $\begin{array}{c}\mathrm{Y}_{\mathrm{E}} \\
\left(\mathrm{kg} \mathrm{ha}^{-1}\right)\end{array}$ \\
\hline \multicolumn{5}{|c|}{$2018(\mathrm{IY})$} \\
\hline \multicolumn{5}{|c|}{ N-Sowing $\left(5 \mathrm{~kg} \mathrm{ha}^{-1}\right)$} \\
\hline$G Y=3108+51.87 x-0.7200 x^{2}$ & $*$ & 0.68 & 35 & 4041 \\
\hline$H M=48.40+0.36 x-0.0054 x^{2}$ & $*$ & 0.64 & 45 & 55 \\
\hline$I Y=1072+33.69 x-0.5200 x^{2}$ & & 0.73 & 35 & 1614 \\
\hline \multicolumn{5}{|c|}{ N-Sowing $\left(25 \mathrm{~kg} \mathrm{ha}^{-1}\right)$} \\
\hline $\mathrm{GY}=3247+59.01 \mathrm{x}-0.8300 \mathrm{x}^{2}$ & $*$ & 0.75 & 35 & 4296 \\
\hline $\mathrm{HM}=51.61+0.28 \mathrm{x}-0.0048 \mathrm{x}^{2}$ & $*$ & 0.88 & 44 & 55 \\
\hline$I Y=1273.70+36.70 x-0.5600 x^{2}$ & & 0.96 & 35 & 1872 \\
\hline \multicolumn{5}{|c|}{$2017(\mathrm{UY})$} \\
\hline \multicolumn{5}{|c|}{$\mathrm{N}$-Sowing $\left(5 \mathrm{~kg} \mathrm{ha}^{-1}\right)$} \\
\hline $\mathrm{GY}=2308+30.01 \mathrm{x}-0.5000 \mathrm{x}^{2}$ & * & 0.88 & 30 & 2758 \\
\hline $\mathrm{HM}=46.42+0.34 \mathrm{x}-0.0058 \mathrm{x}^{2}$ & $*$ & 0.96 & 40 & 51 \\
\hline$I Y=789.55+38.96 x-0.5700 x^{2}$ & $*$ & 0.87 & 35 & 1455 \\
\hline \multicolumn{5}{|c|}{ N-Sowing $\left(25 \mathrm{~kg} \mathrm{ha}^{-1}\right)$} \\
\hline$G Y=2570.40+24.87 x-0.3300 x^{2}$ & * & 0.58 & 30 & 3020 \\
\hline $\mathrm{HM}=45.76+0.35 \mathrm{x}-0.0061 \mathrm{x}^{2}$ & $*$ & 0.88 & 39 & 51 \\
\hline$I Y=1066.30+32.87 x-0.5100 x^{2}$ & $*$ & 0.96 & 35 & 1592 \\
\hline \multicolumn{5}{|c|}{$2016(\mathrm{FY})$} \\
\hline \multicolumn{5}{|c|}{$\mathrm{N}-$ Sowing $\left(5 \mathrm{~kg} \mathrm{ha}^{-1}\right)$} \\
\hline$G Y=3685.10+33.60 x-0.5300 x^{2}$ & * & 0.67 & 40 & 4181 \\
\hline $\mathrm{HM}=52.42+0.3 \mathrm{x}-0.0042 \mathrm{x}^{2}$ & $*$ & 0.93 & 45 & 54 \\
\hline$I Y=1789.10+17.55 x-0.2605 x^{2}$ & $*$ & 0.57 & 45 & 2051 \\
\hline \multicolumn{5}{|c|}{ N-Sowing $\left(25 \mathrm{~kg} \mathrm{ha}^{-1}\right)$} \\
\hline$G Y=3957.20+18.67 x-0.3000 x^{2}$ & $*$ & 0.70 & 40 & 4224 \\
\hline$H M=55.96+0.02 x-0.0005 x^{2}$ & $*$ & 0.99 & 45 & 56 \\
\hline $\mathrm{IY}=2081.80+16.17 \mathrm{x}-0.2300 \mathrm{x}^{2}$ & * & 0.60 & 45 & 2344 \\
\hline
\end{tabular}

$\mathrm{R}^{2}=$ coefficient of determination; $\mathrm{P}$ - Parameter that measures the slope of the line by the probability of T at 0.05 error; N-time - Adjusted ideal time (days after emergence); N-Sowing - Dose of nitrogen applied at sowing; YE - Variable estimated for the ideal season; * significant at $\mathrm{p} \leq 0.05$ by the F test; GY - Grain yield $\left(\mathrm{kg} \mathrm{ha}^{-1}\right) ; \mathrm{HM}$ - Hectoliter mass $\left(\mathrm{kg} \mathrm{hl}^{-1}\right)$; IY - Industrial yield $\left(\mathrm{kg} \mathrm{ha}^{-1}\right)$; IY - Intermediate year; UY - Unfavorable year; FY - Favorable year

In the unfavorable year (2017), the highest grain yield was obtained 30 days after emergence, regardless of the nutrient dose at sowing. The equations established in the low and high nitrogen dose at sowing indicate yield at the ideal time with 2758 and $3020 \mathrm{~kg} \mathrm{ha}^{-1}$, respectively. For the hectoliter mass, regardless of the dose provided at sowing, the ideal time to apply the nutrient in top dressing was around 40 days after emergence, with an estimated value of $51 \mathrm{~kg} \mathrm{hl}^{-1}$ in both conditions. The ideal time for the supply of nitrogen in top dressing has an optimum point 35 days after emergence, regardless of the dose provided at sowing, allowing for a low and high dose of the nutrient at sowing to reach 1455 and $1592 \mathrm{~kg}$ $\mathrm{ha}^{-1}$, respectively, of industrial yield.

In the favorable year (2016), promising results for grain yield were obtained 40 days after emergence, regardless of the nitrogen dose at sowing. The equations established at doses of 5 
and $25 \mathrm{~kg} \mathrm{ha}^{-1}$ at sowing point to an expected yield of 4181 and $4224 \mathrm{~kg} \mathrm{ha}^{-1}$, respectively. In the same year, for the hectoliter mass, regardless of the dose provided at sowing, the ideal time for application in top dressing was at 45 days after emergence, obtaining the value of 54 and $56 \mathrm{~kg} \mathrm{hl}^{-1}$, in both conditions. The ideal time of nitrogen application in top dressing showed an optimum point at 45 days after emergence, regardless of low and high dose of nutrient at sowing, with promising results of 2051 and $2344 \mathrm{~kg} \mathrm{ha}^{-1}$, respectively, of industrial yield.

The use of management practices, such as the adjustment of nitrogen doses and the ideal time of supply can contribute to improve the efficiency of use to increase yield and quality of grains in cereals, reducing nutrient losses to the environment (Valério et al., 2009; Silva et al., 2016; Arenhardt et al., 2017). In wheat, Ercoli et al. (2013) found higher nitrogen efficiency with the application of $30 \mathrm{~kg} \mathrm{ha}^{-1}$ of the nutrient at the time of sowing and the remainder of the total top dressing dose. In canola, Kaefer et al. (2015) observed an increase in the efficiency of nitrogen utilization in the preparation of grains by parceling, with one third at sowing and two thirds at top dressing (40 and $80 \mathrm{~kg} \mathrm{ha}^{-1}$ ) applied at the fourth true leaf stage. Due to the supply of nitrogen in top dressing, Mantai et al. (2015) state that the maximum efficiency of nitrogen fertilization in oats is obtained with the total dose supplied from 70 to $90 \mathrm{~kg} \mathrm{ha}^{-1}$ of nitrogen, this variation being dependent on the condition of the agricultural year and the time of fertilization. Silva et al. (2015) observed changes in the efficiency of nitrogen use in wheat by the type of residual cover of high and reduced carbon/nitrogen ratio, with an optimum dose of 78 and $114 \mathrm{~kg} \mathrm{ha}^{-1}$ of nitrogen in succession systems soybean/wheat and corn/ wheat, respectively. Scremin et al. (2017) analyzed the efficiency of nitrogen use in the yield of oat grains in systems of high and reduced $\mathrm{N}$-residual release, with an adjusted dose of nitrogen at maximum yield of grains with $80 \mathrm{~kg} \mathrm{ha}^{-1}$ and $100 \mathrm{~kg} \mathrm{ha}^{-1}$, respectively. De Mamann et al. (2019), studying nitrogen doses in wheat, observed the maximum technical efficiency of use of the nutrient in grain yield with the dose of $100 \mathrm{~kg} \mathrm{ha}^{-1}$, applied in the phenological stage of the third expanded leaf. In this same study, the use of nonlinear effects of temperature and rainfall were used for simulation by artificial intelligence, indicating an optimal dose with $93 \mathrm{~kg} \mathrm{ha}^{-1}$. Trindade et al. (2006) found in the wheat crop, a reduction in the hectoliter mass with the increase of fertilizer doses in top dressing with the cultivars EMBRAPA 22 and EMBRAPA 42. In beans, Scherer et al. (2015) analyzed the effects of different nitrogen doses and application times. Among the results obtained, the application of nitrogen in top dressing positively influenced the crop, and the total dose of $60 \mathrm{~kg} \mathrm{ha}^{-1}$ of nitrogen applied at 30 days after emergence and half dose of $120 \mathrm{~kg} \mathrm{ha}^{-1}$ in parcels at 15 and 30 days after the emergence showed the best results.

From the emergence to the emission of the sixth leaf is the time when oat plants demand more nitrogen (Mantai et al., 2016). If applied in the initial stages, it favors the maximum number of spikelets and grains in the inflorescence, when applied in the final stages, it can enhance the number of stems per area (Teixeira Filho et al., 2010). In wheat, Arenhardt et al. (2015) verify that the period between the beginning of the tillering and the elongation shows a large interval in the decision of the appropriate moment of application, necessitating besides the most favorable conditions of soil moisture, other elements in dimensioning the dose and 
the most adjusted time of nutrient supply. According to these authors, in years favorable to growing, the timing of fertilization with $\mathrm{N}$-fertilizer was adjusted around 45 days after emergence and in unfavorable years at 35 days. Costa et al. (2013) observed that nitrogen fertilization favored the yield of wheat grains when applied in parcels 20 days after emergence and beginning of the ear. Martins et al. (2014) found that the increase in the mass of wheat grains is normally associated with an availability of nitrogen during the flowering phase and the beginning of grain filling. On the other hand, grains with greater mass do not necessarily guarantee greater yield per area. Prando et al. (2012) reported that the supply of nitrogen fertilizer at different times of application in top dressing affected the yield of wheat grains, but not the hectoliter mass. Still, in wheat, Trautmann et al. (2020) analyzed the efficiency of nitrogen use in different supply conditions. In the soybean/wheat system, the forms of nutrient supply did not change in grain yield. On the other hand, in the corn/wheat system, the more restrictive nitrogen conditions were more dependent on nutrient supply in the early stages of development. For Kolchinski \& Schuch (2003) the industrial quality of oat grains depends on several factors, which may be related to soil conditions, climate, management, such as the dose and timing of nitrogen application, sowing time, cultivar or test employed to assess physiological quality.

The results presented in this study show that the definition of the nitrogen dose in the sowing with the appropriate time of application in top dressing are important strategies in the optimization of the nutrient to the yield and quality of grains with reduction of environmental impacts. Therefore, it is an innovative proposal for nitrogen management in oat crop, which seeks to add fertilizer recommendation criteria involving biological and environmental indicators, in the perspective of a more sustainable management of the nutrient.

\section{Conclusion}

In an unfavorable and intermediate year for the growing of oats, it is necessary to increase the dose of the nutrient at sowing in order to favor a greater amplitude of the time of application in top dressing. In a favorable year, whether high or low, this range of application is guaranteed.

Regardless of the high and reduced dose of nitrogen at sowing, the greatest expression of grain and industry yield occurs with the nutrient applied at 30 and 35 days after emergence in an unfavorable year, 35 days in an intermediate year and 40 to 45 days in a favorable year, respectively.

\section{References}

Arenhardt, E. G., Silva, J. A. G., Arenhardt, L. G., Silva, D. R., Gzergorczick, M. E., Ceolin, G. P., ... Oliveira, A. C. (2017). Technical and agronomic efficiency of oat cultivars as a function of nitrogen availability. Científica, 45(3), 257-270. https://doi.org/10.15361/1984-5529.2017v45n3p257-270

Arenhardt, E. G., Silva, J. A. G., Gewehr, E., Oliveira, A. C., Binelo, M. O., Valdiero, A. C., ... Lima, A. R. C. (2015). The nitrogen supply in wheat cultivation dependent on weather conditions and succession system in southern Brazil. African Journal of Agricultural 
Research, 10(48), 4322-4330. https://doi.org/10.5897/AJAR2015.10038

Bredemeier, C., Variani, C., Almeida, D., \& Rosa, A. T. (2013). Estimativa do potencial produtivo em trigo utilizando sensor óptico ativo para adubação nitrogenada em taxa variável. Ciência Rural, $43(7)$ 1147-1154. https://doi.org/10.1590/S0103-84782013005000080

Costa, L., Zucareli, C., \& Riede, C. R. (2013). Parcelamento da adubação nitrogenada no desempenho produtivo de genótipos de trigo. Revista Ciência Agronômica, 44(2), 215-224. https://doi.org/10.1590/S1806-66902013000200002

De Mamann, A. T. W., da Silva, J. A. G., Binelo, M. O., Scremin, O. B., Kraisig, A. R., Carvalho, I. R., Pereira, L. M., Berlezi, J. D., \& Argenta, C. V. (2019). Artificial intelligence simulating grain productivity during the wheat development considering biological and environmental indicators. Journal of Agricultural Studies, 7(3), 197-212. https://doi.org/10.5296/jas.v7i3.15153

Ercoli, L., Masoni, A., Pampana, S., Mariotti, M., \& Arduini, I. (2013). As durum wheat productivity is affected by nitrogen fertilization management in central Italy. European Journal of Agronomy, 44, 38-45. https://doi.org/10.1016/j.eja.2012.08.005

Kaefer, J. E., Richart, A., Nozaki, M. H., Daga, J., Campagnolo, R., \& Follmann, P. (2015). Canola response to nitrogen source and split application. Revista Brasileira de Engenharia $\begin{array}{llll}\text { Agrícola } & e & \text { Ambiental, } & 19(11),\end{array}$ https://doi.org/10.1590/1807-1929/agriambi.v19n11p1042-1048

Kolchinski, E. M., \& Schuch, L. O. B. (2003). Atributos de desempenho industrial e qualidade de sementes em aveia branca em função da disponibilização da adubação nitrogenada. Ciência Rural, Santa Maria, 33, 587-589. https://doi.org/10.1590/S0103-84782003000300031

Ma, B. L., Zheng, Z., Pageau, D., Vera, C., Fregeau-Reid, J., Xue, A., \& Yan, W. (2017). Nitrogen and phosphorus uptake, yield and agronomic traits of oat cultivars as affected $\mathrm{N}$ rates under diverse environments. Nutrient Cycling in Agroecosystems, 108(3), 2445-265. https://doi.org/10.1007/s10705-017-9848-8

Mantai, R. D., Silva, J. A. G., Arenhardt, E. G., Scremin, O. B., Mamann, A. T. W., Frantz, R., ... Krysczun, D. K. (2016). Simulation of oat grain (Avena sativa) using its panicle components and nitrogen fertilizer. African Journal of Agricultural Research, 11(40), 3975-3983. https://doi.org/10.5897/AJAR2016.10943

Mantai, R. D., Silva, J. A. G., Sausen, A. T. Z. R., Costa, J. S. P., Fernandes, S. B. V., \& Ubessi, C. (2015). A eficiência na produção de biomassa e grãos de aveia pelo uso do nitrogênio. Revista Brasileira de Engenharia Agrícola e Ambiental, 19(4), 343-349. https://doi.org/10.1590/1807-1929/agriambi.v19n4p343-349

Marolli, A., Silva, J. A. G., Romitti, M. V., Mantai, R. D., Scremin, O. B., Frantz, R. Z., ... Lima, A. R. C. (2017). Contributive effect of growth regulator trinexapac-ethyl to oats yield 
in Brazil. African Journal of Agricultural Research, 12(10), 795-804. https://doi.org/10.5897/AJAR2016.11784

Marolli, A., Silva, J. A. G., Sawicki, S., Binelo, M. O., Scremin, A. H., Reginatto, D. C., ... Lambrecht, D. M. (2018). A simulação da biomassa de aveia por elementos climáticos, nitrogênio e regulador de crescimento. Arquivo Brasileiro de Medicina Veterinária e Zootecnia, 70(2), 535-544. https://doi.org/10.1590/1678-4162-9504

Martins, L. M., Zagonel, J., Ferreira, C., \& Senger, M. (2014). Épocas de aplicação de regulador de crescimento e de sombreamento artificial afetando cultivares de trigo. Revista Eixo, 3(1), 47-59. https://doi.org/10.19123/eixo.v3i1.123

Prando, A. M., Zucareli, C., Fronza, V., Bassoi, M. C., \& Oliveira, F. A. (2012). Formas de ureia e doses de nitrogênio em cobertura no desempenho agronômico de genótipos de trigo. Semina: $\quad$ Ciências $\quad$ Agrárias, $33(2), \quad 621-632$. https://doi.org/10.5433/1679-0359.2012v33n2p621

Scherer, A. L., Ribon, A. A., Fernandes, K. L., \& Hermógenes, V. T. L. (2015). Efeito de diferentes épocas e doses de aplicação de nitrogênio na cultura do feijoeiro cultivado em Campo Grande-MS. Revista Cultivando o Saber, 8(2), 162-171.

Scremin, O. B., Silva, J. A. G., Mammann, A. T. W., Marolli, A., Mantai, R. D., Trautmann, A. P. B., ... Dornelles, E. F. (2017). Nitrogen and hydrogel combination in oat grains productivity. International Journal of Development Research, 7(7), 13896-13903.

Silva, J. A. G., Arenhardt, E. G., Kruger, C. A. M. B., Lucchese, O. A., Metz, M., \& Marolli, A. (2015). A expressão dos componentes de produtividade do trigo pela classe tecnológica e aproveitamento do nitrogênio. Revista Brasileira de Engenharia Agrícola e Ambiental, 19(1), 27-33. https://doi.org/10.1590/1807-1929/agriambi.v19n1p27-33

Silva, J. A. G., De Mamann, A. T. W., Scremin, O. B., Carvalho, I. R., Pereira, L. M., Lima, A. R. C., ... Norbert, L. (2020). Biostimullants in the indicators of yield and industrial and chemical quality of oat grains. Journal of Agricultural Studies, 8, 68-87. https://doi.org/10.5296/jas.v8i2.15728

Silva, J. A. G., Goi Neto, C. J., Fernandes, S. B.V., Mantai, R. D., Scremin, O. B., \& Pretto, R. (2016). A eficiência do nitrogênio em aveia na produtividade de grãos com estabilidade. Revista Brasileira de Engenharia Agrícola e Ambiental, 20(12), 1095-1100. https://doi.org/10.1590/1807-1929/agriambi.v20n12p1095-1100

Teixeira Filho, M. C. M., Buzetti, S., Andreotti, M., Arf, O., \& Benett, C. G. S. (2010). Doses, fontes e épocas de aplicação de nitrogênio em trigo irrigado em plantio direto. Pesquisa Agropecuária Brasileira, 45, 797-804. https://doi.org/10.1590/S0100-204X2010000800004

Tonin, R. B., Ranzi, C., Camera, J. N., Forcelini, C. A., \& Reis, E. M. (2014). Amplitude térmica para germinação de conídios de drechslera tritici-repentis. Summa Phytopathologica, 40(2), 174-177. https://doi.org/10.1590/0100-5405/1881

Trautmann, A. P., da Silva, J. A., Binelo, M. O., Valdiero, A. C., Henrichsen, L., \& Basso, N. 


\section{Macrothink}

Journal of Agricultural Studies

ISSN 2166-0379 2020, Vol. 8, No. 4

C. F. (2020). Simulação da produção de trigo por nitrogênio e não linearidade das condições ambientais. Revista Brasileira de Engenharia Agrícola e Ambiental, 24(1), 44-51. https://doi.org/10.1590/1807-1929/agriambi.v24n1p44-51

Trindade, M. G., Stone, L. F., Heinemann, A. B., Canovas, A. D., \& Moreira, J. A. A. (2006). Nitrogênio e água como fatores de produtividade do trigo no cerrado. Revista Brasileira de Engenharia Agrícola e Ambiental, Campina Grande, 10(1), 24-29. https://doi.org/10.1590/S1415-43662006000100004

Valério, I. P., Carvalho, F. I. F., Oliveira, A. C., Benin, G., Maia, L. C., Silva, J. A. G., ... Silveira, G. (2009). Fatores relacionados à produção e desenvolvimento de afilhos em trigo.

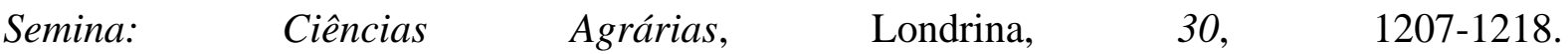
https://doi.org/10.5433/1679-0359.2009v30n4Sup1p1207

\section{Copyright Disclaimer}

Copyright for this article is retained by the author(s), with first publication rights granted to the journal.

This is an open-access article distributed under the terms and conditions of the Creative Commons Attribution license (http://creativecommons.org/licenses/by/4.0/). 